\title{
DO MANAGERS BELIEVE IN THE CORPORATE SOCIAL-FINANCIAL PERFORMANCE LINK?
}

\author{
Ivan Carlo Stocco de Campos \\ Mestre em Economia Internacional pela Lancaster University Management School \\ ivanstocco@gmail.com
}

Juliana Bonomi Santos

Doutora em Management Science pela Lancaster University Management School Professora do Programa de Pós-Graduação em Administração - FEI j.santos@fei.edu.br

\begin{abstract}
The relationship between corporate social and financial performance has already been explored in many empirical studies. Meta-analyses based on these studies confirm that positive financial outcomes result from firms' social strategies. This confirmation should stimulate investments in social actions, practices and processes. However, as managers' beliefs and interests drive their investment decisions, high-level executives may limit firms' investments in social strategies if they are unaware or do not believe in a positive corporate social-financial performance link. This research set out to investigate if managers believe that social actions, practices and processes lead to superior financial performance. Data on the perception of 112 top-managers of Brazilian companies were collected through a survey which shows that, according to highlevel executives, socially-responsible actions have a positive indirect effect on firms' profitability, due to the increase they cause on stakeholders' satisfaction. Managers' decisions to invest in socially responsible strategies are not entirely based on financial returns and, thus, proving the CSP-financial performance link should not be the main focus. Research should now concentrate on the social strategies-stakeholder satisfaction-financial performance link. Top-management beliefs and decision-making processes have to be considered in future studies on the subject. Furthermore, there is the need to consider how much top managers and stakeholders actually know of firms' social strategies and how long does it takes for them to become aware of it. Given these research outcomes, departments responsible for social strategies need to market heavily the positive outcomes of their efforts to assure future investments.

Key-words: Corporate Social Performance, Financial Performance, Stakeholder Satisfaction, Managerial Cognition, Survey, Regression Analyses
\end{abstract}

\section{A ALTA ADMINISTRAÇÃO ACREDITA NA RELAÇÃO ENTRE DESEMPENHO SOCIAL E ECONÔMICO?}

\section{RESUMO}

A relação entre o desempenho social e financeiro das empresas já foi alvo de muitos estudos empíricos. Meta-análises baseadas nesses estudos confirmam a existência de uma relação positiva entre esses conceitos. Isso deveria estimular futuros aportes de recursos. No entanto, não necessariamente a alta gestão acredita nessa relação e, em última instância, são as crenças desses executivos sobre o que funciona ou não em uma empresa que definem suas decisões. Assim, esta pesquisa investigou a percepção da alta administração sobre a relação entre o desempenho social e financeiro das empresas. A percepção de 112 executivos de empresas brasileiras foi coletada por meio de questionários eletrônicos. A análise desses dados mostrou que, para a alta gerência, práticas sociais aumentam a satisfação dos stakeholders e essa satisfação leva a maiores retornos financeiros. As decisões de investimento em ações sociais não são baseadas apenas em taxas de retorno sobre o investimento. Portanto, provar a relação entre desempenho social e financeiro deveria deixar de ser o foco de futuros estudos. Esses deveriam explorar a relação entre ações sociais, satisfação dos stakeholders e desempenho financeiro. É também preciso considerar em futuros estudos aspectos cognitivos e políticos associados à tomada de decisão e entender o tempo necessário para que os resultados de ações sociais sejam assimilados por executivos e outros stakeholders. Para os gestores de ações sociais, o presente estudo indica a necessidade de investir na comunicação e divulgação dos resultados de estratégias sociais para atrair futuros investimentos.

Palavras-chave: Desempenho Social, Desempenho Financeiro, Satisfação dos Stakeholders, Cognição Gerencial, Levantamento de Dados, Análise de Regressão.

Revista de Gestão Social e Ambiental - RGSA, São Paulo, v. 7, n. 3, p. 3-19, out./dez., 2013. 


\section{INTRODUCTION}

The corporate social performance concept started developing back in the seventies and is, still today, a topic of interest (Carroll \& Buchholtz, 2011). The economic perspective challenged these socially-oriented ideals from the start, suggesting that the only corporate objective was value maximization (Jensen, 2001). Such proposition motivated researchers to prove that socially responsible practices bring positive financial returns (Griffin \& Mahon, 1997). Since then, many empirical studies explored the relationship between the social and financial performances of firms (e.g. Bramer \& Millington, 2008; Ceretta, Barba, Casarin, Kruel, Milani, 2009; Crisóstemo, Freire \& Vasconcellos, 2010; Margolis \& Walsh, 2003; McWilliams \& Siegel, 2000; Preston \& O'Bannon, 1997; Simpson \& Koher, 2002; Wood \& Jones 1995), but mixed results were found. This variation has been associated with the high variety of measures used to represent the social and financial performance constructs (Griffin \& Mahon, 1997), the lack of attention devoted to control variables (Andersen \& Dejoy, 2011), and the differences in countries' institutional environments (Baughn, Bodie \& McIntosh, 2007). The good news is perhaps that different meta-analyses on these studies found a positive, albeit mild, association between social and financial performance (Griffin \& Mahon, 1997; Orlitzky, 2001; Orlitzky, Schmidt, \& Rynes, 2003; Orlitzky; 2011; Wu, 2006).

The confirmation that firms' positive attitudes towards society do bring positive financial returns to firms should positively influence managers' decision to invest in social practices. However, managers' bounded rationality makes them rely on simplified views of the world (Simon, 1955) and use their mental models and beliefs to make decisions (Tripsas \& Gavetti, 2000). These mental representations guide how firms' capabilities will be developed and become part of the organization (Lamaanen \& Wallis, 2009). They can be so powerful that even major events may not suffice to change managers' orientations and strategies. At Polaroid, organizational reengineering and the owner's retirement did not change the top-level strategies that led the company to bankruptcy (Tripsas \& Gavetti, 2000). Thus, given the corporate objective of value maximization (Jensen 2001), if managers do not believe that the good management of stakeholders' interests brings positive results to owners and shareholders (Angle et al. 2008), they probably will not support social actions, even if these actions actually do have benefits.

However, little is known on managers' perceptions of the real value of firms' social strategies, as studies have mainly concentrated on the corporate social-financial performance link. This paper will therefore try to answer the following research question: Do managers believe that social plans, actions and programmes lead to superior financial performance? The hypotheses developed were tested using data from a survey on the perception of 112 top-managers of Brazilian companies. Overall the regression analyses showed managers' beliefs differ from what has been found by studies on the corporate social-financial performance link, opening new avenues for future research. This paper continues as follows. First, the relevant literature is reviewed and the hypotheses are formulated. Next, the method used to collect and analyse the data is described. The findings are then summarized and the implications of the results discussed. We conclude and provide suggestions for future research in the last section.

\section{THEORETICAL BACKGROUND}

This literature review first explores the corporate social performance concept and then discusses the relationship between social and financial performance. The final subsection focuses on the influence of managers' cognition on their social investment decisions.

\subsection{Corporate social performance: a theoretical definition}

An initial and seminal definition of corporate social performance was proposed by Carroll (1979). For this author, corporate social performance is a three-dimensional concept composed of the ideas of corporate social responsibility, social issues and social responsiveness. Based on further theoretical developments on the concept (e.g. Wartick \& Cochran, 1985), Wood (1991) proposed

Revista de Gestão Social e Ambiental - RGSA, São Paulo, v. 7, n. 3, p. 3-19, out./dez., 2013. 
that the assessment of social performance required the measurement of the principles guiding social responsibility, of the processes of responsiveness, and of the programmes "designed to manage the firm's societal relationships, and the social impacts (i.e., observable outcomes) of the firm's actions, programs, and policies" (Wood, 1991: p.693). Wood's definition was then refined by Clarkson (1195), who suggests that social performance relates the organization and its stakeholders, while social responsibility and responsiveness are concepts more closely associated with the interests of societies and with political and economic issues. As such, for Clarkson (1995), corporate social performance relates to firm's social endeavours, to stakeholders' satisfaction in relation to these actions and to the responsibility assumed by firms in relation to stakeholders' matters.

Based on these studies, this paper sees corporate social performance (CSP) as a construct composed of two dimensions: 1) the plans, actions, programmes (strategies) firms invest on to satisfy stakeholders, regardless of firms' motivation to undertake them, and 2) stakeholders' satisfaction with these strategies. It follows from this definition that only stakeholders can assess CSP, as they judge their own experiences, other stakeholders' experiences and companies' ability to meet stakeholders' expectations (Wood \& Jones, 1995). Additionally, measuring CSP from only one stakeholder perspective provides a partial representation of firms' social outcomes (Mahon \& Wartick, 2012). Moreover, CSP involves the social strategies implemented to yield social benefits and to improve firms' competitive position in markets (Schuler \& Cording, 2006). Lastly, to measure CSP, there is the need to identify firms' key stakeholders, assess the strategies implemented to satisfy them and measure their satisfaction (Connolly, Conlon \& Deustch, 1980; Hitt, 1988; Zammuto, 1984).

\subsection{The corporate social-financial performance link}

There are two theoretical perspectives on the corporate social-performance link. The first one derives from the economic view that firms' sole objective is to maximize value to owners and shareholders (Jensen, 2001). This branch of literature suggests that there exists a negative relationship between CSP and financial performance at a point in time (Preston \& O'Bannon, 1997; Waddock \& Graves, 1997). Social programmes, like waste reduction, construction of childcare facilities, implementation of flexitime and job sharing journeys, sponsorship of parental leave, and philanthropic programmes, involve the investment of significant amounts of money and other resources (Bramer \& Millington, 2008). Additionally, companies have to maintain a structure to manage these actions (Crisóstomo et al., 2010). As such, social initiatives have costs and deviate important resources from other strategies. Agency problems could also lead managers to invest in these actions to enhance their utility instead of devoting resources to more profitable investments (Bramer \& Millington, 2008).

The second theoretical perspective believes in a positive association between CSP and financial performance. Grounded in the instrumental stakeholder theory (Orlitzky et al, 2003), this view contends that, all other things held constant, managers that perceive the value of stakeholders and pursue their interests will have higher "traditional" outcomes, like returns on investment (Donaldson, 1999). This happens because the good management of stakeholders' interests increases their satisfaction (Angle et al. 2008). Stakeholders then pay back firms in different ways (Jones, 1995). Satisfied employees become more productive and loyal to the company (Chakravarty, 1986). Happy customers become loyal and increase their willingness to pay (Barney \& Clark, 2007; Fornell, Johnson, Anderson, Cha, \& Bryant, 1996). Good community relationships can stimulate governments to provide tax benefits and train better the future work force (Waddock \& Graves, 1997). Actions to reduce waste (Bramer \& Millington, 2008) and increase quality (Flynn, Schroeder \& Flynn, 1999) can also improve efficiency and reduce costs (McWilliams \& Siegel, 2000). Good social behaviour can also improve firms' reputation (Crisóstomo et al. 2010; Donaldson \& Preston, 1995; Preston \& O’Bannon, 1997), captivating customers, reducing price elasticity and attracting socially-concerned investors (Bramer \& Millington, 2008).

Revista de Gestão Social e Ambiental - RGSA, São Paulo, v. 7, n. 3, p. 3-19, out./dez., 2013. 
Independently of the theoretical approach, there are aspects of the competitive environment that influence the CSP-financial performance relationship. Firms' size is such a factor. Smaller firms may lack the financial resources and infrastructure to maintain social actions (Crisóstomo et al., 2010), while larger firms may suffer more pressure for socially-responsible behaviour (Waddock \& Graves, 1997). Furthermore, companies operating in different industries have alternative production processes, quality and safety standards (Simpson \& Kover, 2002), and social and environmental concerns (Chand, 2006). The portfolio of stakeholders also varies depending on the industry (Griffin \& Mahon, 1997; Rowley \& Berman, 2000). Countries' institutional and historical contexts may also influence the regulatory frameworks firms operate in, firms' relationships with their stakeholders and firms' attitude towards CSP (Baughn et al., 2007). Specific factors may also be relevant in particular countries or industries, like R\&D investments and marketing expenses (Andersen \& Dejoy, 2011).

Many empirical studies explored the relationship between the CSP and financial performance (e.g. Bramer \& Millington, 2008; Ceretta et al., 2009; Crisóstemo et al., 2010; Margolis \& Walsh, 2003; McWilliams \& Siegel, 2000; Preston \& O’Bannon, 1997; Simpson \& Koher, 2002; Wood \& Jones 1995). Studies remain inconclusive (Boaventura, Silva \& Bandera-deMello, 2012), mainly due to the use of several measures to represent the CSP and financial performance concepts (Griffin \& Mahon, 1997). However, meta-analyses conducted with the results of these studies provide empirical evidence that supports the second theoretical perspective, albeit partially (figure 1).

Figure 1. The CSP-Financial performance relationships: theoretical and empirically verified

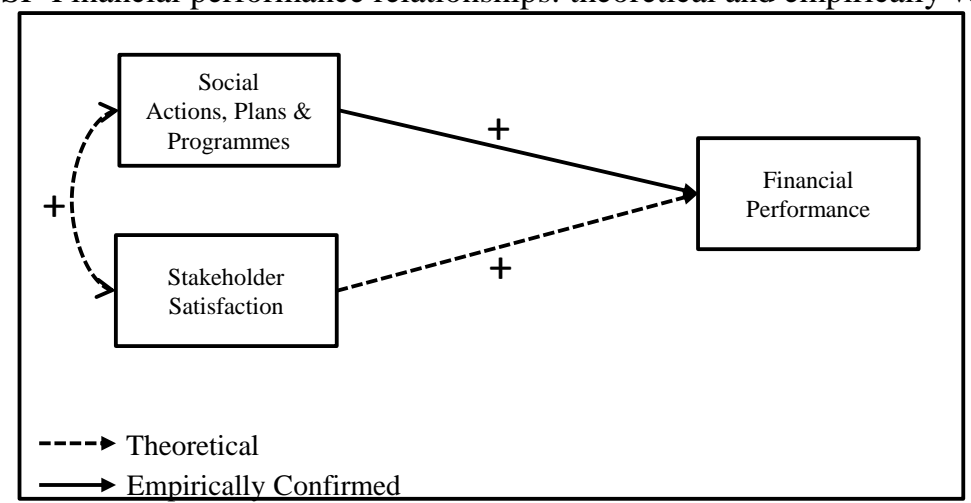

Source: Proposed by the authors (2014)

The meta-analyses show that the social plans, actions, and programmes have a mild, but positive association with financial performance (Griffin \& Mahon, 1997; Orlitzky, 2001; Orlitzky et al., 2003; Orlitzky, 2011; Wu, 2006). This was the case even in studies with an economics, finance and accounting background (Orlitzky, 2011). Orlitzky et al. (2003) and Wu (2006) also found that the intensity of the relationship between social strategies and financial performance depends on how constructs were operationalized. Accounting measures showed higher correlation with social strategies than market-based measures. Higher positive correlations were also found when social strategies were measured with reputation indexes instead of with objective measures. Firms' size also proved to be an important control variable, affecting the intensity of the relationships between social actions, plans and programmes and financial performance (Orlitzky, 2001; Wu, 2006). No meta-analyses on the other two relationships represented in figure 1 were found.

\subsection{The corporate social-financial performance link and managerial cognition}

While it is important to know that social strategies influence positively firms' financial outcomes, as this may reinforce social investments, researchers remained focused on it for a long 
period of time, leaving other important aspects of CSP out (Wood, 2010). For instance, little is known on how managerial cognition affects managers' attitudes towards CSP.

Managerial cognition relates to the mental models, beliefs and heuristics that manager have and use to make their decisions (Tripsas \& Gavetti, 2000). They result from individuals' bounded rationality (Simon, 1955), experiences in the industry (Kaplan, 2011) and backgrounds. Strategic management researchers studying the role of cognition in strategy formulation and implementation showed that these managerial representations of reality influence organizational actions and outcomes (Kaplan, 2011). They shape the resources and capabilities firms develop and accumulate over time (Tripsas \& Gavetti, 2000). In their study of Polaroid, Tripsas \& Gavetti (2000) show that the managers believed in the razor/blade business model adopted by the firm (i.e. customers bought a camera and then kept buying films) and did not accept that the digital technology would revolutionize the market. As a consequence, firm's capability became obsolete and, by the time managers decided to compete in the digital market, the company had no competences for it. Not even a major organizational reengineering process was capable of changing these mental models. The role of managerial cognition is also central in the Penrosian argument (1959) that firms' growth directions depend on managers' decisions in relation to how they will use resources with spare capacity to provide new offerings.

Applying these ideas to context of this paper, we could then say that knowing how managers see the relationship between CSP and financial performance is as important as proving the existence of the relationship. If managers believe CSP reduces profitability, they may cut down investments in social strategies, even if this is not the case. Similarly, they may reduce the amount of resources dedicated to social actions, if they do not see the satisfaction of stakeholders as an important goal. We however still do not know how managers perceive the corporate social-financial performance link, as little attention was dedicated to it. This research thus explores if managers believe in the positive associations between the CSP dimensions and financial performance (as in figure 1) by posing three hypotheses:

H1: According to managers' perceptions, the greater the investment in social plans, actions, and programmes, the greater will be the financial performance of firms.

H2: According to managers' perceptions, the greater the satisfaction of firms'stakeholders, the greater will be the financial performance of firms.

H3: According to managers' perceptions, investment in social plans, actions, and programmes are positively associated with the satisfaction of firms'stakeholders.

\section{METHODOLOGY}

Data from a survey conducted with top managers of Brazilian firms in 2008 was used to test the hypotheses. The respondents of the survey were high-level executives, such as directors, vicepresidents, board members and owners. These executives are the ones responsible for making important investment decisions and, as such, can decide whether or not to implement social plans, actions and programmes.

The selection of indicators was guided by the theoretical definitions of CSP and profitability. Santos (2008), based on the literature and on annual reports of 15 Brazilian firms, suggests that customers, employees, the community and the environment are the most important stakeholders in Brazil. CSP in Brazil was then seen as: 1) the plans, actions, and programmes firms developed to manage the relationship with customers, employees, communities and the environment; and 2) the satisfaction of customers, of employees, and of the people concerned with the community and with the environment. Thirteen variables assessed the investments of companies in issues concerning customers, employees, the community and the environment. Other four indicators measured stakeholders' satisfaction. Profitability was the financial performance dimension studied, as it reflects how well firms employ the money provided by investors (Brigham, Gapenski, Ehrhardt, \& Michael, 1999). The profitability measures used in this study are commonly

Revista de Gestão Social e Ambiental - RGSA, São Paulo, v. 7, n. 3, p. 3-19, out./dez., 2013. 
used in empirical research on the corporate social-financial performance link (Griffin \& Mahon, 1997; Orlitski et al. 2001). The variables used in the study are in table 1.

Table 1: Variables used in the analysis

\begin{tabular}{|c|c|c|}
\hline Construct & Variable & Code \\
\hline \multirow[t]{5}{*}{ Profitability } & Return on assets & ROA \\
\hline & $\begin{array}{l}\text { Return from sales, excluding taxes, interests, } \\
\text { depreciation and amortization }\end{array}$ & Mg_EBTIDA \\
\hline & Return on investments & ROI \\
\hline & Return on sales & ROS \\
\hline & Return on equity & ROE \\
\hline \multirow{4}{*}{$\begin{array}{l}\text { Stakeholders' } \\
\text { Satisfaction }\end{array}$} & Loyalty of customers (repurchase rate) & loyalty \\
\hline & Employees' turnover & Employee_Turnover \\
\hline & Number of environmental lawsuits & Environ_Lawsuits \\
\hline & $\begin{array}{l}\text { Number of lawsuits moved by the community } \\
\text { (including customers and employees) }\end{array}$ & Community_Lawsuits \\
\hline \multirow{3}{*}{$\begin{array}{l}\text { Strategies to } \\
\text { Customers } \\
\text { (Cust_Strat) }\end{array}$} & Conformity to the products and services specifications & Conf_Especifications \\
\hline & Level of defect of products or errors in services & Defect_Level \\
\hline & Reliability of the product or service & Reliability \\
\hline \multirow{4}{*}{$\begin{array}{l}\text { Strategies to } \\
\text { Employees } \\
\text { (Empl_Strat) }\end{array}$} & Competitive wages and benefits & Wages_Benefits \\
\hline & Investment on employees' training & Investiment_Training \\
\hline & Availability of careers plans & Career_Plans \\
\hline & Investment on organizational climate & Organizational_Climate \\
\hline \multirow{4}{*}{$\begin{array}{l}\text { Strategies to the } \\
\text { Environment } \\
\text { (Envir_Strat) }\end{array}$} & Number of programmes to take care of the environment & N_Environmental_Programmes \\
\hline & Programmes to reduce pollutants emissions & Actions_Reduce_Emissions \\
\hline & Use of recyclable inputs & Use_reciclable_imputs \\
\hline & Level of recycling and reuse of waste material & Recycling_Reuse_Waste \\
\hline Strategies to the & Number of employees that come from minority groups & Minorities_Hiring \\
\hline $\begin{array}{l}\text { Community } \\
\text { (Commun_Strat) }\end{array}$ & Number of programmes to take care of the community & N_Community_Programmes \\
\hline Size & Annual net revenues & Dummy_size1, Dummy_size2 \\
\hline
\end{tabular}

Source: Proposed by the authors (2014)

The questions were formulated in the following way: "if compared to the main competitors in the industry, how was the performance of the firm, in the last 3 years, in terms of". The performance indicators were then listed below. A five-point scale ranging from "below average" to "above average" was employed. Individuals were asked to answer the questions with the most recent company they have worked for in mind. As firms' performance was assessed in relation to the industry, a better performance in lawsuits means that the company actually suffered fewer legal prosecutions than the industry average. The turnover indicator should be understood in the same way. We did not specifically asked managers for their opinion to reduce the chances that individuals would answer that CSP influences financial performance. With the question used, we had a better chance of capturing the mental models managers have and are, sometimes, not even aware of. The relative performance measure employed also minimizes the influence of the sector on the data set (Santos \& Brito, 2012). The country effect was not important in this research as the data set contained information on only one country. Additionally, the questions refer to an aggregated period of time, reducing the effect of eventual fluctuations in companies' annual results (Kim, Hoskisson \& Won, 2004). The effect of size was controlled using a proxy of net annual revenues. Two dummies represented three categories of firms' size: up to $\mathrm{R} \$ 50$ million, from $\mathrm{R} \$ 50$ million to $\mathrm{R} \$ 500$ million and more the $\mathrm{R} \$ 500$ million. 
The questionnaire was sent to 2443 top-managers. Their contacts were obtained with the Brazilian Institute of Corporate Governance and with the post-graduation alumni office of a top Brazilian business school. The questionnaires were sent out twice and, in total, 116 people answered the questionnaire; a response rate of $4.7 \%$. Two-population means tests showed no significant $(\mathrm{p}>5 \%)$ differences in the answers of respondents from different sources and response waves. Four questionnaires were eliminated due to the low variation in the respondents' answers. The final sample was composed of answers from 112 high-executives. Individuals’ belonged to a fairly heterogeneous set of firms (table 2).

Table 2. Respondents' profile and their firms

1) Job Title
a) Board Member
b) President
c) Vice-president
d) Director
e) Partner
f) Senior-manager

$\begin{array}{ll}\text { N. of Respondents } & \text { \% of Total } \\ 26 & 23.5 \\ 25 & 22.5 \\ 6 & 5.4 \\ 47 & 42.3 \\ 6 & 5.4 \\ 1 & 0.9\end{array}$

2) Firm Size: Annual net revenue

a) $<\mathrm{R} \$ 50$ millions

b) $\mathrm{R} \$ 50$ millions to $\mathrm{R} \$ 500$ millions

N. of Firms

c) > R\$500 millions

45

31.6

40.5

$31-27.9$

3) Firm Experience: years the firm operates in the sector

\section{N. of Firms}

a) $<10$ years

19

b) 10 to 40 years

c) 40 to 70 years

d) $>70$ years

42

34

16

$\%$ of Total

17.1

37.9

30.6

14.4

4) Firm Sector: Consider business unit with highest net revenues, if firm operates in different sectors

Agriculture, Forestry, Fishing and Hunting

Financial Activities and Insurance

Automation, Technology, Capital Goods

Consumer Goods

Intermediary Goods

Commerce

Construction

Information and Communication Technology, Telecom

Other Services

Note. Sample size of 112

\begin{tabular}{ll} 
N. of Firms & \% of Total \\
2 & 1.8 \\
6 & 5.4 \\
9 & 8.1 \\
21 & 18.9 \\
9 & 8.1 \\
11 & 9.1 \\
9 & 8.1 \\
13 & 11.7 \\
32 & 28.8 \\
\hline
\end{tabular}

Source: Proposed by the authors (2014)

A preliminary data analysis using the statistical software SPSS 18 prepared the data for the main analyses. The frequency distribution and 5-point analyses revealed no significant outliers. Missing values were substituted by the trend point of the data set. The Kolmogorov-Smirnov tests indicated that the variables did not have a normal distribution. Yet, histograms showed distributions approximately normal. This was confirmed by the 5-point analysis: variables average mean (3.57), average standard deviation (0.89), average skewness (-0.26), and average kurtosis (-0.12) were close to the ones expected in normal distributions of five-point scales (c.f. Santos, 2008). Next, we tested the validity and reliability of the measurements. Reliability relates to the consistency between the different indicators used to measure the same concept, while validity indicates if the variables represent the concept measured (Pedhazur \& Schmelkin, 1991).

Exploratory factor analysis (EFA) was used to check constructs' validity, as this technique reveals the underlying dimensions of the dataset (Hair, Anderson, Tatham, \& William, 1998). The EFA had a good fit (Child, 2006); the KMO was 0.84 and the Barlett's test of sphericity was

Revista de Gestão Social e Ambiental - RGSA, São Paulo, v. 7, n. 3, p. 3-19, out./dez., 2013. 
signicant $(\mathrm{p}<0,001 \%)$. The VARIMAX rotated solution extracted six factors (table 3$)$. Factor 1 groups together the profitability indicators. Factor 2 groups the four strategies related with the environment. Factor 3 groups the three strategies oriented to employees. Factor 4 groups conformity to specifications, level of defect, reliability of products and services and loyalty, but loyalty has a low load $(<0.5)$. Factor 5 groups the other three variables of stakeholders' satisfaction. Factor 6 groups the two strategies oriented to the community. These results show the validity of the constructs measurements, as the variables measuring the same concept grouped together in the same factor.

Table 3: Exploratory factor analysis loads and reliability indexes

\begin{tabular}{|c|c|c|c|c|c|c|}
\hline Variables / Factors & $\begin{array}{l}\text { Profita } \\
\text { bility }\end{array}$ & $\begin{array}{l}\text { Strat. for } \\
\text { Customers }\end{array}$ & $\begin{array}{l}\text { Stakeholder } \\
\text { Satisfaction }\end{array}$ & $\begin{array}{l}\text { Strat. for } \\
\text { Employees }\end{array}$ & $\begin{array}{l}\text { Strat. for } \\
\text { Environm. }\end{array}$ & $\begin{array}{l}\text { Strat. for } \\
\text { Commun. }\end{array}$ \\
\hline ROA & .903 & .171 & .114 & .120 & .005 & .021 \\
\hline Mg_EBTIDA & .898 & .176 & .019 & .141 & .046 & -.002 \\
\hline ROI & .915 & .190 & .063 & .222 & .031 & .023 \\
\hline ROS & .877 & .165 & .011 & .069 & .060 & .020 \\
\hline ROE & .915 & .171 & .095 & .101 & .091 & .084 \\
\hline Conf_Specifications & .340 & .680 & .115 & .123 & .204 & -.104 \\
\hline Defect_Level & .203 & .790 & .185 & .061 & .061 & .167 \\
\hline Reliability & .149 & .853 & .073 & .077 & .052 & .042 \\
\hline Loyalty & .375 & .491 & -.137 & .217 & -.113 & -.027 \\
\hline Employee_Turnover & .203 & .113 & .581 & .309 & .140 & .108 \\
\hline Environ_Lawsuits & -.040 & .246 & .716 & -.126 & .407 & -.170 \\
\hline Community_Lawsuits & .049 & -.004 & .848 & .143 & .070 & .257 \\
\hline Wages_Benefits & .111 & .051 & .113 & .836 & .156 & .144 \\
\hline Investment_Training & .177 & .303 & -.037 & .534 & .434 & .289 \\
\hline Career_Plans & .215 & .157 & .045 & .828 & .211 & .152 \\
\hline Organizational_Climate & .280 & .107 & .366 & .597 & .182 & .005 \\
\hline N_Environmental_Programmes & .048 & .052 & .000 & .146 & .836 & .261 \\
\hline Actions_Reduce_Emissions & .004 & .058 & .376 & .218 & .757 & -.026 \\
\hline Use_reciclable_inputs & .057 & .035 & .199 & .161 & .876 & .026 \\
\hline Recycling_Reuse_Waste & .052 & .052 & .063 & .130 & .837 & .254 \\
\hline Minorities_Hiring & -.021 & .039 & .112 & .074 & .163 & .845 \\
\hline N_Community_Programmes & .106 & .052 & .097 & .334 & .289 & .730 \\
\hline Cronbach's Alpha & .960 & 0.73 & .680 & .820 & 0.9 & .700 \\
\hline KMO & .840 & & & & & \\
\hline Barlett's test - chisquare & $1715.200^{*}$ & & & & & \\
\hline
\end{tabular}

Note: ${ }^{*} \mathrm{p}<0.01$

Source: Proposed by the authors (2014)

After the EFA, to assess the reliability of the scales (Pedzhur \& Schmelkin, 1991), the Cronbach's alphas were calculated using the variables representing each factor (table 3). The measures of profitability, strategies to satisfy customers, strategies to satisfy employees, strategies for the community, and strategies for the environment proved to be reliable, as they had alphas higher than 0.7 (Hair et al., 1998). The strategies to satisfy customers construct had its alpha increase to 0.8 when loyalty was excluded from the calculation, indicating that loyalty was, as intended, measuring the satisfaction of customers. The four stakeholders's satisfaction measures had an alpha of 0.68 , below the recommended value (Hair et al., 1998). This makes sense, as the indicators measure the satisfaction of different stakeholders. We then decided to work with the four variables measuring stakeholders' satisfaction separately, instead of grouping them in a scale. For the other constructs, the indicators of each group were added up and divided by the mean to create 
the scales used to measure profitability, the strategies to satisfy customers, the strategies to satisfy employees, the strategies for the community, and the strategies for the environment. These scales and the four stakeholders' satisfaction variables were used to test the proposed hypotheses, as presented next.

\section{DATA ANALYSES OUTCOMES}

This section describes the results of the regression analyses. It is composed of two subsections. The first one presents the regression used to test the managerial perception in relation to how social plans, actions and programmes $(\mathrm{H} 1)$ and stakeholders' satisfaction $(\mathrm{H} 2)$ influence the financial performance of firms. The second subsection contains data on the correlations and regression analyses executed to test the managerial perception on the relationship between social plans, actions and programmes and the satisfaction of the four Brazilian stakeholders (H3). Size was used as a control variable in all regression models.

The evaluation of the quality of the regression models followed the guidelines of Cohen, Cohen, West, and Aiken (2003) and Hair et al (1998). According to Cohen et al. (2003), in regression models, the variables should be normally distributed, the dependent and independent variables should display a linear relationship and the errors of the prediction should be linear, normally distributed and exhibit homoscedasticity (variance of the errors is independent from the predictor variables). As mentioned, all variables had an approximately normal frequency distribution. The ANOVA was significant $(\mathrm{p}<0,001 \%)$ in all regressions, indicating the existence of a linear relationship between the dependent variable and at least one independent variable. The histograms and pp-plots (cumulative distribution of the data) of the standardized residuals indicated residuals were normally distributed. The scatterplots of the standardized and studentized residuals against the predicted variables suggested that the homoscedasticity assumption could have been violated, but the Breusch-Pagan test indicated that this was not the case (Breusch \& Pagan, 1979). As no regression assumptions were violated, we carried on with the analyses.

\subsection{Managers' view on the impact of CSP dimensions on firm profitability}

The regression analysis used to test $\mathrm{H} 1$ and $\mathrm{H} 2$ is better expressed by the formula:

$$
\begin{aligned}
& \operatorname{Prof} .-\beta_{0}+\beta_{1} \text { Cust_Strat }+\beta_{2} \text { Empl_Strat }+\beta_{3} \text { Commun_Strat }+\beta_{4} \text { Envir_Strat }+\beta_{s} \text { Loyalty }+\beta_{8} \text { Turnover }+ \\
& \beta_{7} \text { Envir_Lawsuits }+\beta_{i} \text { Commun_Lawsuits }+\beta_{9} \text { Size } 1+\beta_{10} \text { Size } 2+\varepsilon_{i}
\end{aligned}
$$

The observation over variables rate was 11.1 , above the rate of 5 recommended by Hair et al. (1998). The R-squared was $36.4 \%$ and the adjusted R-squared was $30.1 \%$, indicating that the regression model explained at least one third of the data variability. Boxplots of the standardized, studentized and studentized deleted residuals indicated five possible outliers. The boxplot of the Cook's distance, which measures the influence of the observation on the regression loads, indicated that two values had high influence. A new regression was executed without these seven points. The new R-squared was $43.5 \%$ and the new adjusted R-squared was $37.5 \%$, indicating an improvement in the model fit. The analysis of the residuals revealed no new outliers or points of influence. This was considered the final model. The coefficients of the regression are in table 4.

Table 4: Regression coefficients and collinearity diagnostic

\begin{tabular}{lllll}
\hline & $\begin{array}{l}\text { Unstandardized } \\
\text { Coefficients }\end{array}$ & Std. Error & $\begin{array}{l}\text { Standardized } \\
\text { Coefficients } \\
\text { Beta }\end{array}$ & $\begin{array}{l}\text { Collinearity } \\
\text { Statistics } \\
\text { VIF }\end{array}$ \\
\hline Envir_Strat & .069 & .118 & .065 & 2.03 \\
Commun_Strat & .005 & .099 & .005 & 1.63 \\
Cust_Strat & .163 & .130 & .127 & 1.72 \\
Empl_Strat & $.216^{* * *}$ & .118 & .202 & 2.00
\end{tabular}

Revista de Gestão Social e Ambiental - RGSA, São Paulo, v. 7, n. 3, p. 3-19, out./dez., 2013. 


\begin{tabular}{lllll} 
Loyalty & $.318^{*}$ & .095 & .306 & 1.40 \\
Turnover & $.157 * * *$ & .083 & .183 & 1.58 \\
Envir_Lawsuits & $-.204 * *$ & .101 & -.241 & 2.39 \\
Commun_Lawsuits & $.178^{* * *}$ & .100 & .189 & 1.88 \\
SIZE_DUMMY_1 & -.053 & .155 & -.033 & 1.56 \\
SIZE_DUMMY_2 & .050 & .147 & .034 & 1.67 \\
R-squared $(\%)$ & 37,5 & & & \\
Adjusted R-squared $(\%)$ & 43,5 & & & \\
\hline Note: $* \mathrm{p}<0.01, * * \mathrm{p}<0.05, * * * \mathrm{p}<0.1$ &
\end{tabular}

Source: Proposed by the authors (2014)

The Variance Inflaction Factor (VIF) was smaller than 2.5 for all the variables in the model, suggesting absence of multicollinearity (Hair et al., 1998). The analysis of the regression coefficients showed that the strategies to satisfy employees were the only ones that, in managers' mind, have a significant positive effect on profitability. Even so, the significance level was close to $10 \%$. Strategies to satisfy customers and to manage issues related to the community and to the environmental had no significant association $(\mathrm{p}>0.1)$ with profitability. Based on these results, H1 was not confirmed.

The regression loads of the variables measuring stakeholders' satisfaction were all significant $(\mathrm{p}<0.1)$. Loyalty had the highest standardized load $(0.3)$, level of community lawsuits and employees' turnover had a standardized load close to 0.18 and the level of environmental lawsuits had a standardized load of -0.24. As such, managers do believe that stakeholders' satisfaction influences profitability, confirming $\mathrm{H} 2$. The size dummies were not significant, indicating that managers do not consider size an important aspect. Interestingly, the level of environmental lawsuits had a negative impact on profitability. A high score for the lawsuits variables means that the company had low levels of lawsuits. Managers thus think that firms with low environmental violations also have low profitability.

\subsection{Managers' view on the association between social strategies and stakeholders' satisfaction}

We then performed a correlations analysis (table 5) that showed the existence of association between the social strategies and stakeholders'satisfaction, confirming H3.

Table 5: Means, Standard Deviations and Correlations

\begin{tabular}{lllllllllll}
\hline & \multicolumn{1}{c}{ Correlations } \\
\hline & Mean & S.D. & 1 & 2 & 3 & 4 & 5 & 6 & 7 & 8 \\
Loyalty(1) & 3.7 & 0.74 & 1 & & & & & & & \\
Turnover(2) & 3.6 & 0.86 & .143 & 1 & & & & & & \\
Envir_Lawsuits (3) & 3.9 & 0.86 & -.009 & $0.35^{*}$ & 1 & & & & & \\
Commun_Lawsuits(4) & 3.6 & 0.83 & -.041 & $0.42^{*}$ & $0.49^{*}$ & 1 & & & & \\
Envir_Strat(5) & 3.4 & 0.72 & -.017 & $0.32^{*}$ & $0.44^{*}$ & $0.30^{*}$ & 1 & & & \\
Commun_Strat(6) & 3.44 & 0.78 & .069 & $0.27^{*}$ & .053 & $0.35^{*}$ & $0.44^{*}$ & 1 & & \\
Empl_Strat(7) & 3.41 & 0.67 & $0.26^{*}$ & $0.44^{*}$ & $0.15^{* * *}$ & $0.31^{*}$ & $0.52^{*}$ & $0.48^{*}$ & 1 & \\
Cust_Strat(8) & 3.9 & 0.58 & $0.42^{*}$ & $0.28^{*}$ & $0.30^{*}$ & $0.18^{* *}$ & $0.23^{* *}$ & $0.16^{* * *}$ & $0.40^{*}$ & 1 \\
\hline
\end{tabular}

Note: $* \mathrm{p}<0.01, * * \mathrm{p}<0.05, * * * \mathrm{p}<0.1$

Source: Proposed by the authors (2014)

To increase the robustness of these results, we tested an additional proposition. According to the literature, the good management of stakeholders' interests increases their satisfaction (Angle et al. 2008). As such, we conducted four regressions to test if the social strategies influenced stakeholders's satisfaction. These regressions had the following formulas:

Loyalty $=\beta_{0}+\beta_{1}$ Cust_Strat. $+\beta_{2}$ Empl_Strat $+\beta_{3}$ Commun_Strat $+\beta_{4}$ Envir_Strat $+\beta_{9}$ Size $1+\beta_{10}$ Size $2+\varepsilon_{i}$ 
Turnover $-\beta_{0}+\beta_{1}$ Cust_Strat $+\beta_{2}$ Empl_Strat $+\beta_{3}$ Commun_Strat $+\beta_{2}$ Envir_Strat $+\beta_{0}$ Sizel $+\beta_{10}$ Size $2+\varepsilon_{i}$ EnvirLawsuits $-\beta_{0}+\beta_{1}$ Cust_Strat $+\beta_{2}$ Empl_Strat $+\beta_{3}$ Commun_Strat $+\beta_{i}$ Envir_Strat $+\beta_{5}$ Sizel $+\beta_{10}$ Size $2+\varepsilon_{i}$ CommunLawsuits $-\beta_{0}+\beta_{1}$ Cust_Strat $+\beta_{2}$ Empl_Strat $+\beta_{3}$ Commun Strat $_{-} \beta_{4}$ Envir_Strat $+\beta_{g}$ Sizel $+\beta_{10}$ Size $2+\varepsilon_{i}$

The boxplots of the standardized, studentized, studentized deleted residuals and Cook's distance were analysed to check for possible outliers and points of influence. The regression against loyalty, turnover, environmental lawsuits and community lawsuits had 3, 3,2, 2 points that deserved further attention, respectively. New regressions without these points displayed similar results, better adjusted R-squared, and no new outliers. These were the final models adopted. Key statistics for these regressions are in table 6.

Table 6: Coefficients and collinearity diagnostics of the four regression models

\begin{tabular}{|c|c|c|c|c|c|c|c|c|}
\hline & \multicolumn{2}{|l|}{ Loyalty } & \multicolumn{2}{|l|}{ Turnover } & \multicolumn{2}{|c|}{ Envir_Lawsuits } & \multicolumn{2}{|c|}{ Community_lawsuits } \\
\hline & Std. Coef. & VIF & Std. Coef. & VIF & Std. Coef. & VIF & Std. Coef. & VIF \\
\hline Envir_Strat & $-.241 * *$ & 1.51 & $.250 * *$ & 1.68 & $.568 *$ & 1.43 & .152 & 1.50 \\
\hline Commun_Strat & .045 & 1.50 & -.019 & 1.75 & -.104 & 1.48 & .123 & 1.57 \\
\hline Empl_Strat & $.224 * *$ & 1.74 & $.280 * *$ & 1.73 & -.098 & 1.66 & .111 & 1.68 \\
\hline Cust_Strat & $.476^{*}$ & 1.27 & .141 & 1.23 & $.212 * *$ & 1.33 & $.185^{* * *}$ & 1.35 \\
\hline SIZE_DUMMY_1 & .003 & 1.53 & .115 & 1.46 & .044 & 1.50 & $.251 * *$ & 1.49 \\
\hline SIZE_DUMMY_2 & -.077 & 1.65 & .158 & 1.61 & .126 & 1.62 & .137 & 1.60 \\
\hline R-squared $(\%)$ & 30.5 & & 27.6 & & 37.1 & & 18.9 & \\
\hline $\begin{array}{l}\text { Adjusted R- } \\
\text { squared (\%) }\end{array}$ & 27.8 & & 23.4 & & 33.3 & & 14.2 & \\
\hline
\end{tabular}

Note: $* \mathrm{p}<0.01, * * \mathrm{p}<0.05, * * * \mathrm{p}<0.1$

Source: Proposed by the authors (2014)

The R-squared of the regressions ranged from $18.9 \%$ to $37.1 \%$ and the adjusted R-squared from $14.2 \%$ to $33.3 \%$. The regression measuring the effect of strategies on the level of lawsuits moved by the community was the one with the worst fit. The VIF's were smaller than 5 for all variables in all models, suggesting absence of multicollinearity (Hair et al., 1998). The size of the company was only significant in the regression that had community lawsuits as the dependent variable. The results in table 6 suggest that, for managers, companies' social strategies influence stakeholders's satisfaction.

However, the regressions show that managers do not believe that all actions satisfy all stakeholders. For them, strategies aimed at taking care of customers $(p<0,001)$, employees $(p<0.05)$ and the environment $(\mathrm{p}<0.05)$ tend to influence customers' opinions. Interestingly, actions to take care of the environment, in their opinion, have a negative impact on customers' loyalty. They also believe employees become more satisfied when the company invests in environment- $(\mathrm{p}<0.05)$ and employee-oriented $(\mathrm{p}<0.05)$ practices. On their view, firms are also less liable to environmental lawsuits when they try to reduce environmental damages $(\mathrm{p}<0.01)$ and please customers $(\mathrm{p}<0.05)$ and less liable to community lawsuits when they invest in actions to please customers $(\mathrm{p}<0.1)$.

\section{DISCUSSION}

The present study explored how managers see the corporate social-financial performance link. Hypothesis H2 and H3 were confirmed, suggesting that, for top managers: 1) firms' social actions, plans and programmes are positively associated with stakeholders satisfaction in relation to the company, and 2) firms' with satisfied stakeholders tend to have better financial performance. Our additional analyses further suggest that social strategies cause stakeholders' satisfaction to increase. However, it is interesting that managers only see an indirect effect of social strategies on profitability. Hypothesis 1 was not confirmed. While this lack of association may be due to methodological issues, it could also mean that managers find it difficult to assess which of the several strategies adopted by firms leads to superior performance (Boaventura et al., 2012).

Revista de Gestão Social e Ambiental - RGSA, São Paulo, v. 7, n. 3, p. 3-19, out./dez., 2013. 
As such, for high-level executives, social plans, actions and programmes are worth investing on because the good management of stakeholders' interests increases stakeholders' satisfaction and, ultimately, leads to superior financial returns (Angle et al. 2008). They accept the good management theory, but are not aware of or believe in the positive association between financial outcomes and firms' social strategies found in the meta-analyses (e.g. Griffin \& Mahon, 1997; Orlitzky, 2001; Orlitzky et al., 2003; Orlitzky, 2011; Wu, 2006). The allocation of resources to social actions is thus not primarily based on rational financial investment decisions; they depend on softer issues. For instance, a manager may decide to invest more in actions to please employees because this constituency has power within the organization or because he/she believes in possible productivity gains. In one case the investment may not pay off, while in the other it may. However, this may not be a problem, as executives are concerned with the direct benefits of it, i.e. stakeholders' satisfaction. Managers therefore will keep investing on social strategies because they believe in their long-term returns.

While proving the CSP-financial performance link is important, the attention dedicated to it was perhaps exaggerated, as financial returns are not essentially what drive social investment decisions. Researchers now need to move forward and understand the relationship between social strategies, stakeholders' satisfaction and financial performance further, a point relatively unexplored in the literature (Wood, 2010). In doing this, they will need to consider different aspects.

First, researchers should, as suggested by Wood (2010), explore if social strategies actually do influence the satisfaction of stakeholders. They also need to understand how and in which intensity each action is valued by each stakeholder (Mahon \& Wartick, 2012). As each stakeholder judges its own experiences, other stakeholders' experiences and companies' performance in meeting stakeholders' expectations (Wood \& Jones, 1995), studies also have to consider the opinion of different stakeholders. Furthermore, the academic debate should move forward and consider the time-lag issue. It probably takes some time for stakeholders to see and assess firms's social strategies in order to share their resources and, ultimately, create means to return firms' investments. Most of the current studies on the CSP-financial performance link are cross-sectional. Longitudinal studies are necessary to see how long does it take for social strategies to increase the satisfaction of stakeholders. Research also has to consider how fast and effectively information on firms' social strategies gets to high-level executives and stakeholders, as information intensity influences stakeholders' perceptions of firms' social performance (c.f. Schuler \& Cording, 2006). Lastly, there is the need to understand the different issues motivating and hindering managers' investments in CSP. Decision-making in companies is never straightforward. It involves managers' emotions, preferences and beliefs (Bazerman \& Moore, 2012), owners' wishes (Jensen, 2001), and political games.

From a practical point of view, the outcomes of this research suggest that the departments responsible for social initiatives have to market the outcomes of their efforts, especially the ones associated with stakeholders' satisfaction. They need to make sure managers are aware of these outcomes and invest in communication to share these results with the many stakeholders that evaluate the company.

\section{$5.1 \quad$ Country specificities}

This research also provides insights on how Brazilian managers think. For them, while the satisfaction of all stakeholders is associated with firms' profitability, customer satisfaction is the most important factor influencing profitability. Customers' loyalty had the highest standardized load of the regression using profitability as the dependent variable $(0,318)$. Another aspect is that, for managers, a greater amount of environmental lawsuits is associated with higher profitability, represented by the negative regression load $(-0,204)$. This is initially counterintuitive. However, managers might believe that the savings resulting of the low investment in environmental-friendly practices outweigh the costs with lawsuits.

Revista de Gestão Social e Ambiental - RGSA, São Paulo, v. 7, n. 3, p. 3-19, out./dez., 2013. 
There are also interesting aspects in relation to how Brazilian managers believe they can satisfy their customers, employees, and protect the community. For them, to please customers, firms need to invest in quality, guaranteeing the conformity to the specifications, the low levels of defects, the reliability of products and services and the satisfaction of their employees. However, managers do not think community- and environment-related practices are very appealing to customers. The negative regression load of environmental strategies even suggests that, for executives, customers may be sceptical in relation these "responsible" attitudes. Managers however believe that activities to protect the environment tend to please employees; they may think that employees have an inside view of the firm and know these actions are not compensatory. Lastly, managers do not see actions for the community as a way to please any of the stakeholders.

These managerial perceptions provide a clue of the preferences of Brazilian stakeholders. If these mental models are accurate and translate reality, they confirm the argument of Mahon and Wartick (2012) that there are no "one pleases all" measures. Firms therefore need to learn more about their stakeholders' preferences to identify the practices that will indeed please them. These results also show two aspects of the Brazilian institutional environment in relation to CSP. First, while the satisfaction of all stakeholders is important, Brazilian managers believe that customers deserve extra attention. Secondly, community-related practices are still not very important for customers and employees. This is particularly interesting in the case of Brazil, a country with high social inequality and poverty.

\section{CONCLUSION}

The present study evaluated the perception of top-managers on the relationship between CSP and the profitability of firms. Drawing on data from a survey conducted with 112 high-level executives, we show that managers see social actions, plans and programmes as means to satisfy stakeholders and this then increases the profitability of firms. Researchers now need to move forward and focus on the social strategies-stakeholders' satisfaction-financial performance link. They should also consider the factors influencing managers' decision-making processes, the issues associated with short- and long-term returns, the preferences of different stakeholders and the communication of CSP to stakeholders and managers. This study also provides hints on the institutionalized view of CSP in Brazil, the country in which the study was conducted. Lastly, the research outcomes suggest that firms need to communicate the outcomes of social strategies internally, for top managers to guarantee investment flows, and externally, for stakeholders to guarantee the inflow of resources.

Future studies should test the social strategies-stakeholders' satisfaction-financial performance link, taking into account the various issues that might influence these relationships. Researchers could also explore if social strategies actually lead to superior stakeholder satisfaction in $\mathrm{t} 1$ and then check if stakeholder satisfaction increases profitability in $\mathrm{t} 2$. Qualitative research is also needed to understand the process through which stakeholders become aware of companies' practices and decide to become loyal to the company. Future studies could also explore the interplay between the preferences of the different stakeholders and how these preferences influence firms' decision to invest in each social strategy.

This study does not come without limitations. Although the scales used proved to be reliable and valid, only one indicator was used to represent the satisfaction of each stakeholder. As such, the measurement of these constructs was not as accurate was it could have been. This also led to the use of the regression analysis as the data analysis technique. Therefore, it was not possible to test simultaneously all hypotheses. Lastly, this study did not collect objective indicators to compare managers' mental models to the reality of the Brazilian context and, thus, we could not verify the biases in managers' views. These issues should be addressed in future studies on the topic.

Revista de Gestão Social e Ambiental - RGSA, São Paulo, v. 7, n. 3, p. 3-19, out./dez., 2013. 


\section{REFERENCES}

Andersen, M. L., \& Dejoy, J. S. (2011). Corporate social and financial performance: the role of size, industry, risk, R\&D and advertising expenses as control variables. Business and Society Review, 116(2): 237-256.

Angle, B.R., Donaldson, T., Freeman, R.E., Jensen, M.C., Mitchell, R.K., \& Wood D.J. (2008). Dialogue: towards superior stakeholder theory. Business Ethics Quarterly, 18(2): 153-190.

Barney, J. B., \& Clark, D. N. (2007). Resource-based theory: Creating and sustaining competitive advantage. Oxford: Oxford University Press.

Baughn, C., Bodie, N., \& McIntosh, J. (2007). Corporate social and environmental responsibility in Asian countries and other geographical regions. Corporate Social Responsibility and Environmental Management, 14(4): 189-205.

Bazerman, M. H., \& Moore, D. A. (2008). Judgment in managerial decision making. New York: Wiley.

Boaventura, J. M. G., Silva, R. S. D., \& Bandeira-de-Mello, R. (2012). Corporate financial performance and corporate social performance: methodological development and the theoretical contribution of empirical studies. Revista Contabilidade \& Finanças, 23(60): 232-245.

Brammer S., \& Millington A. (2008). Does it pay to be different? An analysis of the relationship between corporate social performance and financial performance. Strategic Management Journal, 29: $1325-1343$.

Breusch, T.S., \& Pagan, A.R. (1979). A simple test for heteroscedasticity and random coefficient variation. Journal of the Econometric Society, 47(5): 1287-1294.

Brigham, E. F., Gapenski, L.C., Ehrhardt, M. C., \& Michael C. (1999). Financial Management: theory and practice. Orlando: Harcourt Brace College Publishers.

Carroll, A. B. (1979). A three-dimensional conceptual model of corporate social performance. The Academy of Management Review. 4: 497-506.

Carroll A. B., \& Buchholtz, A. K. (2011). Business and society: ethics and stakeholder management. South-Western: Cengage Learning.

Ceretta, P. S., Barba, F., Casarin, F., Kruel, M., \& Milani, B. (2009). Desempenho financeiro e a questão dos investimentos sócio-ambientais. Revista de Gestão Social e Ambiental, 3(3): 72-84.

Chakravarthy, B. (1986). Measuring strategic performance. Strategic Management Journal, 7 (5): 437-458.

Chand, M. (2006). The relationship between corporate social performance and corporate financial performance: industry types as a boundary condition. The Business Review, Cambridge, 5 (1): 240245.

Child, D. (2006). The essential of factor analysis. London: Continuum International Publishing Group Ltd. 
Clarkson, M.B.E. (1995). A stakeholder framework for analyzing and evaluating corporate social performance. The Academy of Management Review, 20(1): 92-117

Cohen, J., Cohen, P., West, S.G., \& Aiken, L.S. (2003). Applied multiple regression/ correlation analysis for the behavioural science. New Jersey: Lawrence Erlbaum Associates.

Connolly, T., Conlon, E.J., \& Deutsch, S.J. (1980). Organizational effectiveness: a multipleconstituencies approach. Academy of Management Review, 5 (2): 211-217.

Crisóstomo V.L., Freire F.S., \& Vasconcellos, F.C. (2010). Corporate social responsibility, firm value and financial performance in Brazil. Social Responsibility Journal, 7 (2): 295-309.

Donaldson, T. (1999). Response: making stakeholder theory whole. Academy of Management Review, 24 (2): 237-241.

Donaldson, T., \& Preston, L. E. (1995). The stakeholder theory of the corporation: concepts, evidence and implications, Academy of Management Review, 20: 65-91.

Flynn, B.B., Schroeder, R.G., \& Flynn, J. (1999). World class manufacturing: an investigation of Hayes and Wheelwright's foundation. Journal of Operations Management, 17(3): 249-269.

Fornell, C., Johnson, M.D., Anderson, E.W., Cha, J., \& Bryant, B.E. (1996). The American customer satisfaction index: nature, purpose and findings. Journal of Marketing, 60(4): 7-18.

Griffin, J.J., \& Mahon, J.F. (1997). The corporate social performance and corporate financial performance debate: twenty-five years of incomparable research. Business and Society, 36 (1): 533.

Hair Jr, J., Anderson, R. E., Tatham, R. L., \& William, C. (1998). Multivariate data analysis. Upper Saddle River: Prentice Hall.

Hitt, M.A. (1988). The measuring of organizational effectiveness: multiple domains and constituencies. Management International Review, 28(2): 28 - 40.

Jensen, M.C. (2001). Value maximization, stakeholder theory, and the corporate objective function. Journal of Applied Corporate Finance, 14(3): 8-21.

Jones, T.J. (1995). Instrumental stakeholder theory: a synthesis of ethics and economics. The Academy of Management Review, 20(2): 404-437.

Kaplan, S. (2011). Research in cognition and strategy: reflections on two decades of progress and a look to the future. Journal of Management Studies,48(3): 665-695.

Kim, H., Hoskisson, R. E., \& Wan, W. P. (2004). Power dependence, diversification strategy, and performance in keiretsu member firms. Strategic Management Journal, 25(7): 613-634.

Laamanen, T., \& Wallin, J. (2009). Cognitive dynamics of capability development paths. Journal of Management Studies, 46(6): 950-981. 
Mahon, J., \& Wartick, S. L. (2012). Corporate social performance profiling: using multiple stakeholder perceptions to assess a corporate reputation. Journal of Public Affairs, 12(1): 12-28.

Margolis, J. D., \& Walsh, J. P. (2003). Misery loves companies: rethinking social initiatives by business. Administrative Science Quarterly, 48:268-305.

McWilliams, A., \& Siegel, D. (2000). Corporate social responsibility and financial performance: correlation or misspecification? Strategic Management Journal, 21(5): 603-609

Orlitzky, M. (2001). Does frm size comfound the relationship between corporate social performance and firm financial performance? Journal of Business Ethics, 33(2): 167-180.

Orlitzky, M., Schmidt, F.L., \& Rynes, S.L. (2003). Corporate social and financial performance: a meta- analysis. Organization Studies, 24: 403-441.

Orlitzky, M. (2011). Institutional Logics in the Study of Organizations. Business Ethics Quarterly, 21(3): 409-444.

Pedhazur, E.J., \& Schmelkim, L. Measurement, design and analysis: an integrated approach. Hillsdale: Lawrence Erlbaum Associates Publishers.

Penrose, E. T. (1995). The theory of the growth of the firm. Oxford: Oxford University Press.

Preston, L.E., \& O'Bannon, D.P. (1997). The corporate social-financial performance relationship. Business and Society, 36(4): 419-430

Rowley, T., \& Berman, S. (2000). A brand new brand of corporate social performance. Business \& Society, 39(4): 397-418.

Santos, J. B. (2008). Uma proposta de conceituação e representação do desempenho empresarial. (Master Dissertation). Retrieved from Biblioteca Digital FGV, 61060100577.

Santos, J.B., \& Brito, L.A.L (2012). Towards a subjective measurement model for firm performance. Brazilian Administrative Review, 9(special issue): 95-117.

Schuler, D. A., \& Cording, M. (2006). A corporate social performance-corporate financial performance behavioural model for consumers. Academy of Management Review, 31(3): 540-558.

Simon, H. A. (1955). A behavioural model of rational choice. Quarterly Journal of Economics, 69: 99-118.

Simpson, W.G., \& Kohers, T. (2002). The link between corporate social and financial performance: evidence from the banking industry. Journal of Business Ethics, 35: 97-109.

Tripsas, M., \& Gavetti, G. (2000). Capabilities, cognition, and inertia: evidence from digital imaging. Strategic Management Journal, 21(10-11): 1147-1161.

Waddock, S.A., \& Graves, S.B. (1997). The corporate social performance-financial performance link. Strategic Management Journal, 18(4): 303-319. 
Wartick, S.L. \& Cochran, P.L. (1985). The evolution of the corporate social performance model. Academy of Management Review, 10 (4): 758-769

Wood, D. J., \& Jones, R. E. (1995). Stakeholder mismatching: a theoretical problem in empirical research on corporate social performance. International Journal of Organizational Analysis, 3: 229267.

Wood, D. J. (1991) Corporate social performance revisited. Academy of Management Review, 16: 691-718.

Wood, D. J. (2010). Measuring corporate social performance: a review. International Journal of Management Reviews, 12(1): 50-84.

$\mathrm{Wu}, \mathrm{M}$. L. (2006). Corporate social performance, corporate financial performance, and firm size: a meta-analysis. Journal of American Academy of Business, 8(1): 163-171.

Zammuto, R.F. (1984). A comparison of multiple constituency models of organizational effectiveness. Academy of Management Review, 9(4): 606 - 616.

Data da submissão: 28/09/2013

Data da publicação: 13/12/2013

Revista de Gestão Social e Ambiental - RGSA, São Paulo, v. 7, n. 3, p. 3-19, out./dez., 2013. 